\title{
'LIKE A BIRD WITH THE GIFT OF REASON': MAXIMUS OF TYRE ON THE FREEDOM OF DIOGENES THE CYNIC
}

\author{
J More (Stellenbosch University)
}

\begin{abstract}
In his thirty-sixth oration, Maximus of Tyre draws on Greek philosophical and literary traditions, including the myth of the Golden Age, to encourage his audience to emulate Diogenes the Cynic. While some consider Maximus a philosophical dilettante, I argue here that this oration serves, rather, as an example of a popular philosophy.
\end{abstract}

Keywords: Maximus of Tyre; Second Sophistic; Diogenes; Cynic freedom; popular philosophy.

\section{Introduction}

Some time during the reign of Commodus (180-192 CE), Maximus of Tyre produced a dialexis - a popular discourse or philosophical sermon - in which he holds up the life of the Cynic Diogenes as an ideal after which his hearers should strive. In Oration 36, Maximus presents Diogenes as someone who, by enacting

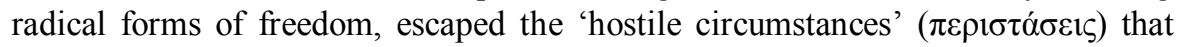
plague all human beings. Maximus draws on various philosophical and literary traditions and topoi in his attempt to encourage his audience to follow Diogenes's example. Against those who have tended to see Maximus as a second-rate philosopher, I will show that Maximus occupies a specific position among the intellectuals of the Second Sophistic. His writing about Diogenes provides us with an example of popular philosophical teaching from the second century.

Our sources say very little about Maximus. They place him in the second half of the second century CE, link him to Tyre, and identify him as having spoken in Rome on at least one occasion. ${ }^{1}$ Apart from this, all we see of this figure is the shadow cast by his extant forty-one speeches. The majority of these relatively short sermons ${ }^{2}$ focus on ethical matters. A handful touch on theology, physics,

For a discussion of these sources and their claims, see Trapp 1997a:xi-xii; Lauwers 2015:1-3.

2 While Maximus identifies his works simply as 'discourses' ( $\lambda$ ó $o \mathrm{l})$ or 'reflections' $(\sigma \kappa \varepsilon ́ \mu \mu \alpha \tau \alpha)$, the texts are called 'investigations' $(\zeta \eta \tau \eta \dot{\mu} \mu \tau \alpha)$ in the Suda and 'discussions' ( $\delta 1 \alpha \lambda \dot{\varepsilon} \xi \xi 1 \zeta)$ in the manuscript titles (Trapp 1997a:xl-xli); see also Lauwers 2015:125-132. In order to signal what I take to be the more popular style employed by Maximus, I will follow Michael Trapp's language in his $A N R W$ essay in which he identifies these texts as 'philosophical sermons' delivered by a 'preacher' (1997b:1950, 1975). 
psychology, and epistemology; not one of them addresses logic. Throughout his sermons, Maximus avoids technical philosophical jargon in order to offer his hearers 'a relatively simple and undemanding form of philosophy' (Trapp 1997b:1949).

Some modern scholars identify Maximus as a sophist, while others have labelled him a Halbphilosoph. ${ }^{3}$ These terms are used to highlight the lack of philosophical depth and sophistication in Maximus's sermons. In contrast to this negative assessment, Jeroen Lauwers (2015) has recently argued that if attention is given to Maximus's self-presentation and to the nature of his texts in the context of other Imperial intellectuals, the Tyrian should be recognised as a philosopher, albeit one engaging in a particular mode of philosophy. Maximus presents his hearers with accessible instruction in Greek culture and philosophy, not purely for the sake of knowledge, but that they might live well.

In his first sermon, ${ }^{4}$ Maximus expresses scepticism about the pursuit of a certain type of activity identified as 'philosophy' by some:

If you think that philosophy is simply a matter of nouns and verbs, or skill with mere words, or refutation and argument and sophistry, and of time spent on accomplishments like that, then there is no problem in finding a teacher. The world is full of that kind of sophist, and their brand of philosophy is easy to acquire; the quest is soon over (Or. 1.8.1-5). ${ }^{5}$

Here, Maximus denigrates sophistry and a type of philosophy that is overly concerned with definitions. Similarly, in Oration 21, Maximus cites a Platonic precedent (Prot. 358a-b) and claims for himself a certain 'freedom over terminology' (21.4.10-11). He is thus dismissive of those who are overly concerned with words, arguments, and definitions.

Maximus claims to offer something different to these sophists. ${ }^{6}$ He presents himself as an expert in proper philosophy and declares that:

3 Sophist: e.g., Dillon 1977:232, 399; Bowersock 2004:60. Halbphilosoph: see the references in Lauwers 2013:331 n. 1. Writing about Lucian, Graham Anderson defines the Halbphilosoph as 'the rhetorical writer who concerned himself with moral (and very often religious) commonplace' (1982:64).

4 For the programmatic nature of this text, see Koniaris 1982:106.

5 English translations of Maximus are from Trapp 1997a. The Greek text is taken from the Teubner edition (Trapp 1994) reproduced online by Thesaurus Linguae Graecae.

6 Philostratus's Lives of the Sophists reminds us that the debate over where to draw the line separating sophists from philosophers is an ancient one. Eshleman 2012 and Lauwers 2015 have sought to situate this debate in the socio-cultural world in which these intellectuals wrote and spoke in order to demonstrate how and why these categories are constructed by the participants in this debate. 
The summit of philosophy and the road that leads there demand a teacher who can rouse young men's souls and guide their ambitions. His task is to temper their desires ... (1.8.13-15).

And earlier in Oration 1, Maximus speaks of his philosophical project in terms of the pursuit of virtue (1.4.18). Maximus's own description of his task establishes the individual's moral progress as its ultimate goal. This ethical focus, combined with his popularising tendency, suggests that we recognise Maximus as contributing to the phenomenon of popular philosophy. ${ }^{7}$

The 'popular philosophy' in view here is difficult to define with any precision. ${ }^{8}$ It is possible to construct a profile of popular philosophy by examining those texts that are considered part of this phenomenon. Johan Thom identifies the following as characteristic of popular philosophy in the Hellenistic-Roman world:

an emphasis on ethics rather than other more technical philosophical topics; a tendency towards selecting doctrines and ideas from various sources rather than staying within one tradition; a focus on the moral progress of the individual rather than a social ethic; psychagogical principles and practices to promote and support spiritual maturity; and the tendency to popularize philosophical ideas (2012:295).

In what follows, I will show how Maximus's sermon on Diogenes's way of life fits snugly within Thom's definition of popular philosophy. That Maximus should be considered as a proponent of popular philosophy is not a novel thesis. ${ }^{9}$ What I hope to do here is to show how one particular example of a popular philosophical sermon is circumscribed by this definition.

\section{The golden and iron way of life}

Maximus begins his exhortation with, as he describes it, an Aesop-like fable $(\mu \tilde{v} \theta \mathrm{o} \varsigma)$ in which Zeus commands Prometheus to colonize the earth with human beings. Prometheus populates the earth with human beings who then lead 'an easy

7 Use of the phrase 'popular philosophy' to speak of Hellenistic-Roman texts that focus on practical ethics is usually traced back to Konrat Ziegler's entry 'Plutarchos von Chaironeia' in the Realencyclopädie (1951). For further discussion, see Van Hoof 2010:1-7; Thom 2015:49-56.

8 Marie-Odile Goulet-Cazé 2007 describes popular philosophy in terms of a collection of ethical topoi presented in an appealing way that aims to bring about moral change in its audience. Similarly, Troels Engberg-Pedersen refers to 'a more or less connected set of philosophical ideas in ethics that has no distinct profile as belonging to this or the other hairesis, but is rather shared by all or most of them' (2017:23).

$9 \quad$ See Goulet-Cazé 2007 and Thom 2015:53. 
life' (Or. 36.1.12). Although Maximus knows Plato's Protagoras ${ }^{10}$ he is not at this point drawing from the creation myth found in Plato's dialogue (Protag. 320c322d). Instead, he alludes to those versions of the myth in which Prometheus creates humankind from clay. ${ }^{11}$ The humans created by Prometheus live in a perfect climate in which the Nymphs provide water in clear springs and the earth brings forth food without the intervention of farmers.

Living as they did off the rich resources that came to them of their own accord, there was nothing they needed to fight over. ... [People lived] a life that knew no wars and no iron weapons, ${ }^{12}$ that was peaceful and had no need of garrisons, where nothing was fought over, a healthy life that lacked for nothing; it would seem that 'the golden race' is Hesiod's teasing term for this era (Or. 36.1.20-27).

While Maximus directs his audience's attention to Hesiod (Op. 109-126) as one of his sources, the Myth of the Golden Age is a topos found throughout Greek and Latin literature (Baldry 1952). ${ }^{13}$ In keeping with this tradition, Maximus describes an earlier, idealised world of plenty in which people live in peace with the world and with each other.

In good Platonic form, Maximus proposes to proceed from $\mu \tilde{v} \theta 0 \varsigma$ to $\lambda$ ó $\gamma \circ \varsigma_{,}{ }^{14}$ in order to draw a comparison between this golden way of life and what he calls the 'iron' way of life (36.2.3). The Iron Age describes the coming of civilization. In this period, people have

divided the earth up into lots and have each carved out of it separate portions, surrounding them with enclosures and walls ... building shelters and adding inner and outer doors and porches (36.2.4-6, 10-12).

People no longer inhabit the 'grassy meadows and tree-covered hills' of the Golden Age (36.1.13-14), but dwell in homes and cities. On view is the ancient contrast between living according to nature (Golden Age) and living according to human custom in the oĩkoৎ and $\pi$ ó $\lambda 1 \zeta$ (Iron Age). Maximus is already preparing his

10 See, e.g., Or. 21.4.

11 E.g., Ovid, Met. 1.82-88; Horace, Carm. 1.16.13-16. Carol Dougherty (2006) discusses the figure of Prometheus and its reception.

12 By mentioning 'iron weapons,' Maximus alludes to the way of life he will describe in the following section.

13 Maximus follows Hesiod and the Greek tradition of referring to a 'golden race'

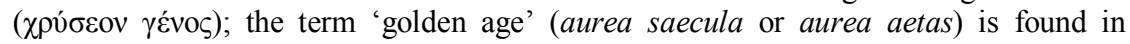
Augustan and post-Augustan Latin literature (Baldry 1952:87-90).

14 See Plato, Protag. 324d. Maximus does not reproduce a Platonic philosophical position at this point, but a Platonic 'method' of moving an argument forward. The same method is on view at $O r$. 14.3.1. 
audience to accept that the Cynic way of life, marked as it is by an appeal to nature, is to be preferred.

The Iron Age marks a departure from the ideal presented in the Golden Age in other ways. Whereas the golden race had sufficient resources so that 'there was nothing they needed to fight over' (36.1.20-22), the race of iron is in a state of disunity and strife. They are enslaved by their love of luxury: 'cramping their necks, their heads, or their fingers with gold, in a form of bondage' (36.2.8-9). The earth, sea, and air - along with the animals that occupy these regions - are harassed. Most striking, however, is the terrible combination of cognitive dissonance and discontent that plagues those who are part of the iron race.

Maximus uses over half of this section (36.2.21-45) to describe the various sites of tension experienced by the individual:

... pursuing pleasant experiences and entangling themselves in painful ones; grasping after wealth, forever convinced that what they have is inferior to what they do not, and that what they have acquired is less than what they look forward to; fearing want, but unable to satiate themselves; fearing death, but taking no thought for life ...

Dio Chrysostom's sixth oration, to which Maximus is, in all likelihood, indebted (Trapp 1997a:282), contains a similar passage. Dio adopts the voice of Diogenes the Cynic to argue that, contrary to popular belief, the Persian king is the most miserable man alive (6.35):

When sober, he longed for intoxication in the belief that he would then have relief from his misfortunes, and when drunk, he imagined himself to be ruined just because he was unable to help himself. And further, when awake, he prayed for sleep that he might forget his fears, but when asleep he would immediately leap up, imagining that his very dreams were killing him (6.36-37; trans. Cohoon [LCL]).

The contrast in Dio is between Diogenes and the Great King, whereas in Maximus, the contrast is between those who belong to the golden race and the iron race. In both cases, however, the contrast is between those who enjoy a self-sufficient contentment and those who are unable to exercise mastery over their desires.

This focus on individual virtue can be contrasted with the way the myth is used by two writers known to Maximus: Aratus and Plato. ${ }^{15}$ Degeneration is also in view in Aratus's version of the myth (Phaenomena 96-136). Aratus uses the myth to explain the gradual disappearance of justice among humankind. Initially, justice

15 For Maximus's use of Aratus, see Or. 24.1. For his use of the Protagoras, see Orr. 2.2; $18.5 ; 21.4 ; 27.8 ; 30.1 ; 31.4$. 
dwelt on earth with the golden race. With the advent of the silver race, she dwelt in the hills, keeping her distance. Finally, when the bronze race was born, 'verily did Justice loathe that race of men and fly heavenward and took up that abode' (133-135; trans. Mair [LCL]). The myth in Protagoras is more about human development than degeneration. In the explanations and arguments that follow it (222d-224d), however, the myth is once again related to questions of society and justice. Even if Maximus notes the social conditions that pertain in each of the two ages he describes, he points his audience to the nature of the individual.

In the next section (3.1-4.8), Maximus addresses his hearers to ask which of these two ways of life is to be preferred. He is not shy of stacking the rhetorical deck:

What man is so witless and ill-starred in his passion and so wretched that, for love of minor and ephemeral pleasures and disputed goods and uncertain hopes and ambivalent prosperity, he would refuse to change his ways and migrate to certain happiness? And that knowing that he will free himself of many times as many ills, which, mixed up as they are in the second style of life, must inevitably surround its living with hostile circumstances, making it wretched and wholly miserable? (4.1-8).

If calling them the 'golden' and 'iron' way of life did not make it sufficiently clear to his audience, by the end of this section, there is no doubt as to which way of life Maximus is recommending.

The second way of life experiences 'conflict and dissension,' it is 'not simple, but constrained and pitiable and loaded with painful circumstances' (36.3.1, 4-5). It is marked by pleasures, but these are accompanied by pain (36.3.11-12). The first way of life, on the other hand, is 'the simple life, untroubled by external circumstance, and secure in the possession of its freedom' (36.3.3-4). Although the Golden Age is also described as a 'peaceable, unconfined, wantless, pain-free existence' (36.3.16-17), it is freedom, above all, that defines it. ${ }^{16}$ As we will see, the language here anticipates the description of Diogenes in Or. 36.5-6 and the type of life to which Maximus is exhorting his audience.

Maximus introduces the ideal type that Diogenes embodies by describing the inhabitant of the Golden Age as 'that naked, homeless, craftless one, ${ }^{17}$ the citizen and inhabitant of the whole world' (

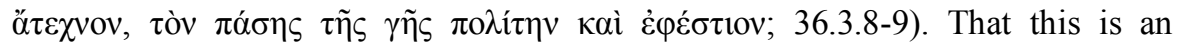

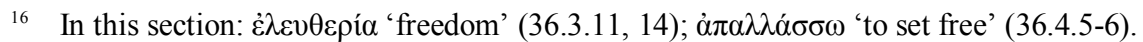

17 The description of the inhabitant of the Golden Age as $\alpha$ or $\tau \chi v 0 \varsigma$ comes from versions of the myth (Aeschylus' Prometheus Unbound; Plato's Protagoras) in which Prometheus introduces fire and, by extension, technology to humankind. For this version of Prometheus, see Dougherty 2006:75-84. 
allusion to Diogenes is clear from the way the Cynic is described elsewhere. Epictetus's Diogenes says that he is 'without a house (óorкos), and without a city

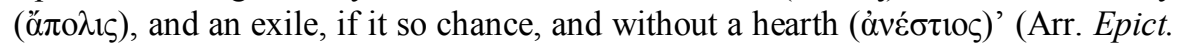
diss. 4.11.23; trans. Oldfather [LCL]; cf. 3.22.47). Similarly, Diogenes Laertius

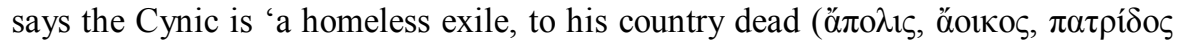

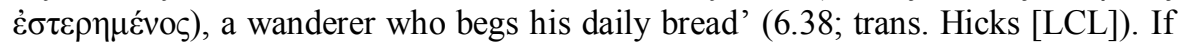
the Diogenes portrayed by these writers is 'without a hearth' and 'bereft of a homeland', Maximus's figure is the more positive, cosmopolitan one - a 'citizen and inhabitant of the whole world' ${ }^{18}$ This is in keeping with the positive portrayal of life in the Golden Age that is free from traditional boundaries.

In the final part of his sermon in which the two ages are contrasted (36.4.832), Maximus demonstrates his Platonic heritage with an allusion to Plato's allegory of the cave (Resp. 514a-517c). Those in the Iron Age live as prisoners in the darkness, 'laden with heavy fetters on their feet and heavy rings around their necks and their hands tied in rough bonds' (36.4.11-14). These are the same people who adorn with gold their necks, heads, and fingers (36.2.8-9). Furthermore, in this prison one hears 'groans and song, lamentation and jubilation together' (36.4.1921). Maximus drives home the same point made earlier: that pleasure is always accompanied by pain (36.3.11-12).

In contrast to this imprisoned way of life, the life of those in the Golden Age is like 'a man living in the pure light of day, with no bonds on his hands or feet, able to move his neck in any direction he wishes, gazing towards the sun' (36.4.21-24). In this section, the note of freedom that first rang out in the description of the Golden Age receives a Platonic modulation.

The myth of the Golden Age and its comparison with the Iron Age, together with the reworking of Plato's cave allegory, serve as a backdrop to the stage upon which Maximus places the Cynic sage Diogenes.

\section{Diogenes}

Maximus begins the climactic section of his sermon by turning to Diogenes the Cynic as an example of one "who lived his life not under the reign of Cronus, ${ }^{19}$ but in the midst of this present race of iron' (36.5.2-4). Although the Cynic is initially unnamed, Maximus expects his audience to recognise this 'native of Sinope in

18 See, e.g., Diog. Laert. 6.63; Arr. Epict. diss. 3.22.22. We also see Epictetus's Cynic forgoing traditional loyalties in order to be a messenger, scout, and herald to the whole world (3.22.69).

19 A reference to the Golden Age. 
Pontus' (36.5.8-9) who was 'liberated by Zeus and by Apollo' (36.5.4-5) ${ }^{20}$ The most characteristic feature of this figure is his freedom.

Maximus echoes the Cynic tradition that defines Diogenes in terms of his freedom: ${ }^{21}$

Counselled by Apollo, he freed himself from all oppressive circumstances and, releasing himself from their bonds, travelled freely about the world (36.5.9-11).

The counsel Diogenes received from Apollo through the Delphic oracle was to 'deface the currency', which was understood in terms of breaking with law and custom..$^{22}$ This act is also associated with Diogenes' departure from Sinope, and hence, is seen as the cause of his exile and paradoxical freedom. Through his actions, Diogenes 'freed himself from all oppressive circumstances ( $\pi \varepsilon \rho ı \sigma \tau \alpha ́ \sigma \varepsilon 1 \zeta)$ ' and travelled the world like 'a bird with the gift of reason' (36.5.9-11). The bird imagery speaks of freedom, while the focus on Diogenes' mind draws our attention to his status as a philosopher. These two aspects of Diogenes' person make him an ideal figure for Maximus' purposes in this particular philosophical sermon.

According to Maximus, Diogenes is free from tyrannical rule, laws and constitutions, marriage and rearing children, and from having to work (36.5.12-20). In view here is the Cynic political - or rather, anti-political - tradition, which denigrates all aspects of civic and communal life that, in the rest of the classical tradition, played such a central role in defining the good life. ${ }^{23}$ In the final part of his sermon (36.6), Maximus will argue that by avoiding these things altogether, Diogenes was able to escape the oppressive circumstances they created (see below).

20 The figure in question is only identified as Diogenes later in this section, at Or. 36.5.46 and Or. 36.6.1. In Or. 34.9.9 he remains anonymous and is identified only as 'the athlete from Pontus'. Diogenes is not unique is this regard. Aesop, for example, is identified simply as 'the sage of Lydia' (36.1.1). The confidence that Maximus has when it comes to his audience's ability to recognise these figures suggests that we are dealing with a group that has at least a basic knowledge of the Greek literary and philosophical tradition.

21 See, e.g., Diogenes Laertius: 'the manner of life he [Diogenes] lived was the same as that of Heracles when he preferred liberty ('่ $\lambda \varepsilon v \theta \varepsilon \rho i \alpha \varsigma)$ to everything' (6.71).

22 For the slogan 'defacing the currency' (Diog. Laert. 6.20) as a critique of society, see Goulet-Cazé 2019:33-36; Branham 1996.

23 Ps.-Diogenes Ep. 47; Diog. Laert. 6.29, 38, 54, 63, 72; Luc. Vit. Auct. 9. See, further, Branham 2007:72, 75-76; Goulet-Cazé 2019:36-37. 
Another topos frequently employed by writers about Diogenes was that his happiness was greater than that of the Great King. ${ }^{24}$ According to Maximus, Diogenes 'lived the life of a free and fearless king' (36.5.20-21). ${ }^{25} \mathrm{He}$ then contrasts the traditional exemplar of luxury and softness, the Persian king, with Diogenes. The Cynic sage is able to enjoy a life that is, from his perspective, even more comfortable and pleasant than the king's, but without the attendant concerns, since the sage lives in accordance with nature. He migrates in concert with the seasons. 'His palaces were temples and gymnasia and groves, his treasure the richest and most secure and the least plotted-against of all, the whole earth and its fruit and springs that are born of the earth' (36.5.24-27). The allusions to the way of life in the Golden Age are unmistakable. Two separate but related aspects of the Diogenes tradition are in view at this point. First, Maximus explains Diogenes's success by the fact that he lived according to nature (36.5.32-33). Second, by living according to nature, the sage is completely independent and self-sufficient. Maximus ignores the fact that, in the Golden Age, self-sufficiency was easily achieved as a result of the abundance produced by the earth, while in the Iron Age it is achieved only through asceticism. ${ }^{26}$

Finally, Maximus argues that Diogenes enjoyed a life of peace (36.5.37-47). In Dio Chrysostom, the philosopher claims to

go by night whithersoever I will and travel by day unattended, and I am not afraid to go even through an army if need be, without the herald's staff, yea, and amid brigands; for I have no enemy, public or private, to block my way (6.60; trans. Cohoon [LCL]).

It is unclear from Dio why this should be the case for Diogenes. Is it because of his status as an exile / cosmopolitan? Certainly, the boundary-less cosmopolitan life without walls and other divisions described in the Golden Age would ensure that war was eliminated. Even though he raised it earlier in his sermon, Maximus does not return to this theme. He explains, instead, that

Criminals and tyrants and informers alike left him [Diogenes] alone, because he could show up the wicked not with sophisticated arguments,

24 Arr. Epict. diss. 3.22.60; Luc. Vit. auct. 9. As mentioned before, Maximus seems to draw on Dio Chrysostom's sixth oration, at the heart of which stands thist contrast between Diogenes and the Great King.

25 This theme is raised again in Or. 36.6 where Diogenes's life is declared to be superior to that of Lycurgus, Solon, Artoxerxes [sic], and Alexander.

26 On Cynic asceticism, see Goulet-Cazé 2019:45-49. On the existence of an 'austere' versus a 'mild' Cynicism, see Malherbe 1982:48-59. Goulet-Cazé (2019:59-71) argues that the differences between Cynics should be attributed to their individual personalities, rather than to different 'types' or sects of Cynics. 
which is the most painful way to be shown up, but by confronting deeds with deeds on each new occasion (36.5.41-45).

As Dudley writes of the historical Diogenes, 'He endeavoured to convert men to a truer way of life, not, like Socrates, by dialectic, nor by allegory, as did Antisthenes, but by the practical example of his daily life' (Dudley 1937:28). The stories that circulated about Diogenes in Maximus's day seemed to confirm this assessment of the Cynic philosopher. This emphasis on deeds over words also provided an implicit critique of those Maximus identifies as 'sophists', who give great attention to clever words but ignore virtue. ${ }^{27}$

The Golden Age was marked by a peace achieved by the fact that everyone had what he or she needed: 'where nothing was fought over, a healthy life that lacked for nothing' (36.1.24-25). This is not a peace that is attainable through individual virtue. By confronting his opponents with his virtue expressed in deeds, Diogenes ensured that he was left alone. This is the peace of the recluse.

After illustrating Diogenes's freedom with examples from the Diogenes tradition that he was able to connect implicitly to the Golden Age, Maximus concludes his sermon by appealing to his audience to follow Diogenes's example. 'How then could this life of Diogenes's, which he chose of his own free will, which Apollo granted him, which Zeus approved, which all men of sense admire, fail to be preferable?' (36.6.1-3).

The last section contains the closest Maximus gets to philosophical definitions in this sermon. The 'hostile circumstances' ( $\pi \varepsilon \rho 1 \sigma \tau \alpha \dot{\sigma \varepsilon \varepsilon 1 \zeta)}$ that Diogenes's freedom allows him to escape are defined as 'the performance of activities that the agent has not freely chosen' (36.6.4-5). Maximus is not explicit about why these are necessarily evil. His logic seems to be that 'hostile circumstances' are evil because these are actions that are forced upon us when we choose the wrong ends instead of being freely chosen actions. ${ }^{28}$

Every man who chooses these objectives [family, work, etc.] has to live through a life beset by circumstance, and to endure labours that are neither voluntary, nor yet accepted in ignorance of those goods that truly deserve choice in their own right (36.6.12-14).

At the heart of the Cynic life is freedom; this has been thrust of Maximus's sermon up until this point. True freedom must include the ability to choose to live in such a way as to avoid those things judged to be undesirable and to choose those things

27 For disparagement of sophists, see Or. 1.8. Or. 15.6: If Heracles chose a life of leisure, he would have been considered a 'sophist.' In Or. 20.3, sophists mimic philosophers, but they differ from philosophers in virtue.

28 I am here following Trapp (1997a:288 n. 35). 
that are truly good. Diogenes's radical solution is to avoid completely things like marriage and children and political participation, thus ensuring that any undesirable circumstances are also avoided.

Maximus lists six categories of people who might be considered free, but who are in reality not: the demagogue, orator, tyrant, general, sailor, and philosopher. Demagogues are enslaved to the crowds, orators to stern jurors, tyrants to their own hedonism, generals to the vagaries of fortune, and sailors to 'an unstable science'. Each of these figures is enslaved since they lack the freedom to determine their own fate; they are required to make choices about something they perceive as a good, following which something or someone external to them can potentially bring about a situation that is unfavourable to them. Demagogues might choose a certain path in order to achieve power, only to realise that subsequent actions are forced upon them by the crowds. They are thus not truly free.

It is at first surprising that Maximus includes the philosopher in this list. Has he not already demonstrated that the philosophical life is preferable? It is specifically the Cynic life that is preferable in this sermon, not any version of the philosophic life. After all, as he proves from history, the two brightest stars in the philosophical galaxy (at least as far as Maximus is concerned) - Socrates and Plato - were both subject to hostile circumstances beyond their control. On this count, then, they prove themselves less worthy of emulation than Diogenes who, by choosing the golden way of life even while living in the world of iron, was able to free himself from hostile circumstances.

At first glance, this seems like a radical prescription, even for a Cynic. Would it be possible to avoid choosing any course of action that might possibly lead to 'hostile circumstances'? This seems unlikely. In other Cynic texts, the sage is able to adapt to his or her circumstances in order to endure them in such a way that their equanimity is not disturbed. Philosophy taught Diogenes to be prepared for any fate (Diog. Laert. 6.63) and the way philosophy achieved this was to cultivate self-sufficiency and independence in the Cynic sage. More often than not, asceticism achieved this self-sufficiency for the sage. According to Theophrastus, by watching a mouse scurrying about, "not looking for a place to lie down in, not afraid of the dark, not seeking any of the things which are considered to be dainties, he [Diogenes] discovered the means of adapting himself to circumstances' (Diog. Laert. 6.22; trans. Hicks [LCL]). The Cynic is thus able to transcend a potentially hostile circumstance like scarcity through ascetic practices which train the sage to endure scarcity with equanimity.

But it is also possible to avoid hostile circumstances altogether. Teles says that one must live like a sailor: 'looking to the winds and circumstances: if favorable, use them; if not favourable, stop' (Teles On circumstances 6.25-27; trans. O'Neil). Although this might suggest adaptability, it could also point to a 
different approach in which negative experiences are avoided rather than endured. There is a tension at this point that can be glimpsed elsewhere.

With regard to the weather, for example, Maximus writes that Diogenes would move from Attica to the Isthmus according to the seasons, not between Bablyon and Persia like the Great King (36.5.20-24). In Dio Chrysostom Or. 6.1-7 this movement is explained in terms of Diogenes's modest climatological needs that are contrasted with the grandiose movements of the king. However, in Maximus, a few lines later, we are told that Diogenes 'made no attempt to run away from the seasons Zeus sends, or to work against him by creating artificial heat in the winter and desiring cooling measures in the summer' (36.5.29-32). In the second case, Diogenes's asceticism allows him to endure the extremes of summer and winter. In the first case, Diogenes adapts to the weather by moving and avoiding the extremes. ${ }^{29}$

We might identify two Cynic approaches to hostile circumstance: endure or avoid. Maximus uses the example of Diogenes to encourage his audience to adopt the second approach. More subtly, though, in the name of freedom, he exhorts them to consider the steps they might need to follow in order to reach a particular good. If a particular good forces 'hostile circumstances' upon them, then they would best avoid that good.

\section{Conclusion}

Maximus of Tyre's sermon on choosing the Cynic way of life as exemplified in Diogenes (Oration 36) matches closely the characteristics of popular philosophy described by Thom (2012):

First, there is a definite focus on ethics at the expense of more technical topics and more technical analyses. With the exception of 'hostile circumstances', $\pi \varepsilon \rho ı \tau \alpha^{\alpha} \sigma \varepsilon \iota \varsigma$, Cynic technical vocabulary is absent from this sermon.

Second, ideas are sourced from across the boundaries that divided the ancient philosophical schools. We have seen Maximus draw on a range of literary and philosophical topoi. In particular, we should note Maximus's innovative incorporation of the example of Diogenes and the Golden Age myth. ${ }^{30}$

Third, the goal of this speech is to encourage moral progress on the part of the individual student, rather than to assert a social ethic or to encourage the

29 Even in this case, though, the fact that he does not have to move as far as the Great King suggests something of his modest needs. On Cynic 'liberty from the seasons', see Martin 1997:103-104.

30 Trapp notes that the link between the Golden Age and Diogenes is unusual (1997a:282). On the more general relationship between myth and the Cynic life, see Martin 1997. 
student to develop such a social ethic. The freedom to which this sermon points is a personal freedom that the individual must use for the purpose of their happiness.

Fourth, while principles and practices of spiritual or moral guidance are not directly in view in this speech, other sermons in the collection suggest that this was indeed a concern for Maximus. ${ }^{31}$

Finally, Maximus is clearly engaged in a process of popularizing the philosophical ideas inherited from his sources. We might note, at this point, that his efforts at popularizing these ideas coincide with his desire to show his facility with the Greek philosophical and literary tradition that was so important in his day. ${ }^{32}$

Maximus thus engages in a mode of popular philosophical rhetoric in order to encourage his audience to pursue a type of Cynic independence that it best thought of in terms of freedom. As is the case with modern intellectuals who engage the broader public through online media, newspaper columns, and self-help books, Maximus's philosophical prowess cannot be judged solely on the basis of these sermons. We cannot say with certainty whether the intellectual limitations of his sermons are indicative of poor philosophy or accommodating communication. If we assume that Maximus is deliberately contributing to popular philosophy and filling a niche between the showy rhetoric of the Sophists and the philosophers' discussion of language and logic then we can attribute a certain skill to Maximus, even if his writings fall short of philosophical prowess.

\section{BIBLIOGRAPHY}

Anderson, G 1982. Lucian: A sophist's sophist. In Later Greek literature, ed. J J Winkler \& G Williams. Yale classical studies 27:61-92. Cambridge: Cambridge University Press.

Baldry, H C 1952. Who invented the golden age? Classical Quarterly 2.1-2:83-92. Bowersock, G W 2004. Artemidorus and the Second Sophistic. In Paideia: The world of the Second Sophistic, ed. B Borg. Millennium studies in the culture and history of the first millennium CE, vol. 2:53-63. Berlin: De Gruyter.

Branham, R B 1996. Defacing the currency: Diogenes' rhetoric and the invention of Cynicism. In The Cynics: The Cynic movement in antiquity and its legacy, ed. R B Branham \& M-O Goulet-Cazé. HCS vol. 23:81-104. Berkeley: University of California Press.

2007. Exile on Main Street: Citizen Diogenes. In Writing exile: The discourse of displacement in Greco-Roman antiquity and beyond, ed. $\mathrm{J} \mathrm{F}$

31 This is an important theme in the programmatic first oration.

32 Lauwers suggests Maximus might have spoken on Diogenes and freedom in response to a request from his audience or in order to demonstrate the extent of his repertoire (2015:242-244). 
Gaertner. Mnemosyne. Bibliotheca Classica Batava, vol. 83:71-85. Leiden: Brill.

Dillon, J M 1996. The middle Platonists: A study of Platonism 80 BC to AD 220.

Revised edition with a new afterword. Ithaca: Cornell University Press.

Dougherty, C 2006. Prometheus. Gods and heroes of the ancient world. London: Routledge.

Dudley, D R 1937. A history of Cynicism: From Diogenes to the 6th century AD London: Methuen.

Engberg-Pedersen, T 2017. Introduction: A historiographical essay. In From Stoicism to Platonism: The development of philosophy, 100 BCE-100 CE, ed. T Engberg-Pedersen, 1-26. Cambridge: Cambridge University Press.

Eshleman, K 2012. The social world of intellectuals in the Roman Empire: Sophists, philosophers, and Christians. Greek culture in the Roman world. Cambridge: Cambridge University Press.

Goulet-Cazé, M-O 2007. Popular philosophy. Brill's New Pauly 11:617-18. 2019. Cynicism and Christianity in antiquity. Trans. C R Smith, foreword by J S Kloppenborg. Grand Rapids: Eerdmans.

Koniaris, G L 1982. On Maximus of Tyre. Zetemata I. Classical Antiquity 1:87-121.

Lauwers, J 2013. Systems of sophistry and philosophy: The case of the second sophistic. Harvard Studies in Classical Philology 107:331-63.

2015. Philosophy, rhetoric, and sophistry in the High Roman Empire: Maximus of Tyre and twelve other intellectuals. Mnemosyne. Supplements, vol. 385. Leiden: Brill.

Malherbe, A J 1982. Self-definition among Epicureans and Cynics. In Jewish and Christian Self-Definition. Vol. 3, Self-Definition in the Graeco-Roman World, ed. B F Meyer \& E P Sanders, 46-59. London: SCM Press.

Martin, T W 1997. The Chronos myth in Cynic philosophy. Greek, Roman, and Byzantine Studies 38.1:85-108.

Thom, J C 2012. Popular philosophy in the Hellenistic-Roman world. EC 3.3:27995.

2015. Paul and popular philosophy. In Paul's Graeco-Roman context, ed.

C Breytenbach. BETL, vol. 277:47-74. Leuven: Peeters.

Trapp, M B, ed. 1994. Maximus Tyrius Dissertationes. Bibliotheca scriptorum Graecorum et Romanorum Teubneriana. Stuttgart: Teubner.

ed.1997a. Maximus of Tyre: The philosophical orations. Oxford: Clarendon Press.

1997b. Philosophical sermons: The Dialexeis of Maximus of Tyre. ANRW 2.34.3:1945-76. 
Van Hoof, L 2010. Plutarch's practical ethics: The social dynamics of philosophy. Oxford: Oxford University Press.

Ziegler, K 1951. Plutarchos von Chaironeia. RE 21.1:636-962. 